This item was submitted to Loughborough's Research Repository by the author.

Items in Figshare are protected by copyright, with all rights reserved, unless otherwise indicated.

\title{
The EU's proxy war on refugees
}

\section{PLEASE CITE THE PUBLISHED VERSION}

https://doi.org/10.13169/statecrime.8.1.0080

\section{PUBLISHER}

Pluto Journals @ International State Crime Initiative

\section{VERSION}

AM (Accepted Manuscript)

\section{PUBLISHER STATEMENT}

This paper was accepted for publication in the journal State Crime Journal and the definitive published version is available at https://doi.org/10.13169/statecrime.8.1.0080. The publisher's website is at: http://www.plutojournals.com.

\section{LICENCE}

CC BY-NC-ND 4.0

\section{REPOSITORY RECORD}

Hintjens, Helen, and Ali Bilgic. 2019. "The Eu's Proxy War on Refugees”. figshare.

https://hdl.handle.net/2134/38058. 
Accepted version 


\title{
THE EU'S PROXY WAR ON REFUGEES
}

\author{
Helen Hintjens and Ali Bilgic
}

\begin{abstract}
For decades, European Union (EU) member states have fought an illegal proxy war - a form of state crime - against refugees and migrants, far beyond EU external borders. Fatalities make this proxy war equivalent to international classifications of war. To justify this war, migrants have progressively been reclassified by the EU as "illegal" or criminal. This article situates the proxy war within wider deterrence-based EU migration policies. Examples like the 2008-2009 Italy-Libya deal and 2016 EU-Turkey deal show the high price paid by refugees, minorities and the damage to the EU's own stability and reputation. Forcibly confining people at "holding points" along migratory routes, expelling people to unsafe countries and raising barriers to legal movement, the violence of the proxy war became more visible in 2015 . We conclude that far from counteracting the dynamics of mass displacement, the proxy war may have contributed to the recent crisis of refugee reception in Europe.
\end{abstract}

Keywords: proxy war; refugees; EU; Turkey; Libya; deaths; Kurds; Mediterranean; deterrence; containment

"Sorry, we simply can't afford to save your life", is said to the dying. The really sad part is that the excuse is not a lie, but the truth - so many are dying not because capitalism is failing but because it is succeeding, because it is fulfilling its logic - a fact that seems more and more visible today than at any other time in recent history.

(Cazdyn 2007: 656)

Since at least the early 1990s, a military logic has underpinned policies designed to dissuade migrants, including refugees, from moving towards, and into, the territories of European Union (EU) member states. Such policies are based on deterrence, which can be defined as ". . . thwarting those seeking to land before they reach sovereign territory” (Mountz and Loyd 2013: 178). According to these authors, "(p)ractices that [are believed to] deter migrants include interception at sea, arrangements to return those intercepted, and detention of those making unauthorized entry somewhere during the transnational journey" (Mountz and Loyd 
2013). As deterrence has become a more explicit policy goal, the "EU proxy war" has become more visible, and the need to end it more apparent.

It can be noted that "Wars of aggression are, by far, the most destructive and destabilizing of all state crimes" (Kramer and Michalowski 2005: 446). We view the EU proxy war on refugees as a war of aggression, waged primarily through state proxies (see Mumford 2013). In this war, policies of exclusion within Europe are perpetually reinforced by violent containment "far away". There are many different battlefields in this proxy war, which has potentially global reach and is being fought across the African continent, in South Asia and the Middle East, the Balkans and the Caucuses. Other versions of the proxy war are those of Israel, which now sells refugees from one African country to another, and Australia, which forces asylum seekers "off shore". This article focuses solely on the EU, however, and suggests the proxy war on refugees may reflect some deeper EU problems of legitimacy (Mitzen 2018).

That the threat of migration to the EU is imagined rather than actual does not mitigate the liability of EU member states for the fatal results of the proxy war. Their actions remain illegal and can be viewed as a form of state crime, as defined by Kramer and Michalowski (2005), and involving

... any action that violates public international law, international criminal law, or domestic law when these actions are committed by individuals acting in official or covert capacity as agents of the state pursuant to expressed or implied orders of the state, or resulting from state failure to exercise due diligence over the actions of its agents. (447-448)

When those in flight are shot by border guards, are raped and tortured, have their organs harvested, remain with untreated injuries and illnesses, or are allowed to drown in the ocean, this is all attributable to the proxy war. Indeed, the proxy war is what ensures that it is precisely those most entitled to seek state protection under international law, who are least likely to be able to receive it. The most desperate for sanctuary are systematically denied the basic human right to move to a place where they can expect the protection they are legally entitled to. Instead they are actively pursued by army and police, and by private gangs, and are persecuted on behalf of EU member states by their paid proxies, wherever they seek protection (Bilgic 2013; Grewcock 2010; Weber and Pickering 2011).

EU member states' preferred modus operandi has been to contractually tie allied states, whether in Africa, the Middle East or elsewhere, into a series of multi-lateral and bi-lateral agreements. These involve extending the geographical scope of EU policing, imposing exclusionary and deterrence-based measures, in exchange for development funding and "security sector" reform. This process of enlarging the geographical scope of EU migration management is not new, as Mitzen reminds us. 
As she also explains, it has more to do with the internal preoccupations of the EU than with any established threat from migrants or refugees. As she puts it,

... this securitization, which began well before $9 / 11$, has been an externalisation of internal security threats. Unemployment and crime have been primarily domestic problems. By expelling [these] ... from the domestic and making it [the security threat] an alien thing brought in by outsiders . . . the EU bought some measure of cohesion. (Mitzen 2018: 407)

This makes the very interesting point that internal difficulties in the EU are being projected onto migrants and states in the "Global South".

Some might suggest the EU is merely waging a war of words, a metaphorical war, like a "war on poverty" or a "war on corruption". Yet, the evidence involves many thousands of casualties, and costs millions of Euros, feeding a growing security industry. In this way, the proxy war does great "social harm" to some of the weakest and most vulnerable people on the planet. The battlefronts of this proxy war now extend from the Sahel to the Balkans, and from the Canaries to Afghanistan. When deterrence has failed, the EU has even considered waging open warfare itself. Thus, in 2015, in response to the "migration crisis", some EU member states set their sights on waging an open "war on smugglers". The plan was that

Fifteen ships, aircraft and drones from at least $10 \mathrm{EU}$ countries will be used to monitor the activity of smuggling boats carrying migrants from Libya to Italy. Their mission will be to decide whether it will be possible to mount full-scale combat operations against the smugglers in future. (Kingsley 2015)

Against this backdrop of militarism, we draw on our own work over several decades as academics engaged with civil society to defend refugee rights, and working with refugees' self-organizations in countries as diverse as Uganda, Australia, Turkey, the UK, Rwanda, the Netherlands, France and Italy. Our engagement has informed our analysis of the proxy war on refugees as a state crime, constructed through the justificatory argument of a supposed threat of "invasion" by migrants and refugees. This is a classic case of securitization and has been considered elsewhere (Boswell 2007; contributors in Lazaridis and Wadia 2015). We propose that the proxy war on refugees and migrants and direct military attacks on smugglers are both illegitimate and counterproductive. The various technologies of exclusion designed to deter migrants and asylum seekers, in practice, may do the opposite by forcing migrants and refugees ever onwards (Bilgic 2013; Hintjens et al. 2011). The proxy war brings regimes of military violence, mass human rights violations and overt state violence against residents, back into EU 
spaces, by the backdoor. Normalization of the use of violence against unarmed "enemies" has brought the idea of warfare closer, making it thinkable and less of a taboo (Mitzen 2018). The EU's borders with Turkey are really not that far away from the spiralling proxy war in Syria; the possibility does arise that the EU or some of its member states could become embroiled in a direct, rather than a proxy war, fought on European soil.

The proxy war is fluid since ". . . boundaries demarcating states, regions and territorial waters are at once sites of policing and containment . . . and sites of crossing and confusion" (Mountz and Loyd 2013: 176; see also Migreurop 2007). Although violence inflicted on migrants and refugees by a proxy is meant to prevent those people reaching the EU, recently, deaths on the way have started to be better documented (International Organization for Migration [IOM] 2014, 2017). In this article, we first consider the meaning of "proxy war", linking it with containment and deterrence. We highlight the resurgence of Turkish army attacks on Kurds, following the EU-Turkey agreement. We examine some examples of agreements between the EU and third countries located along migrant routes, such as Libya and Turkey. We suggest that by "turning a blind eye" to violent persecution and future peace within the EU, the EU and its member states have generated doubts around the supposed foundation of the entire EU project, which was constructed on the premise of a "liberal" form of peace designed to avoid statelessness (Mitzen 2018; for the surprisingly similar Australian case, see Grewcock2010).

\section{Why "Proxy War"?}

The term "proxy war" is surprisingly rare in the academic literature, in view of the prevalence of the phenomenon of proxy war in reality. It is used to refer to situations such as Ukraine or Syria, where several external parties are fighting one another indirectly, by backing local allies, or proxies whom they also arm and fund (Hughes 2014). In "proxy wars", the external actor provides arms, logistical support and even moral justifications which seek to make the war appear legitimate. Geraint Hughes (2014) notes that proxy war is often based on "a prevalence of direct assistance, the existence of a common enemy and the maintaining of the relationship for a certain period of time" (105). Mumford (2013) defines proxy war as ". . . indirect engagement in a conflict by third parties wishing to influence its strategic outcome" (40). Paffenroth (2014) talks of "outsourcing conflict", referring to the frequency with which private actors such as security companies are involved in today's wars. Whilst some level of agreement on a common enemy helps cement the proxy war relationship, as already mentioned, these relations can also be based on loose and pragmatic alliances, for instance, grounded in mutual financial interests or on transactional ties. 
Arguably, in the case of the EU, a low-level proxy war on people in flight, refugees and migrants started at least twenty years ago, or more, and has since intensified (Andersson 2012; Migreurop 2007; Mountz and Loyd 2013). The externalization of EU border controls through multi-lateral "Eurosur" deals across the Mediterranean and through bi-lateral intergovernmental agreements, for example, between Libya and Italy, represents a pragmatic form of "development conditionality". Under such arrangements, “. . . in return for financial aid, non-EU countries hold back irregular migrants and prevent their entry into European territories" (Palladino and Gjergji 2016: 3). Ultimate responsibility rests with the "commissioning" EU states, who could in future find themselves accused of state crimes. The routinization of such policies is no guarantee that human rights violations will be viewed as legitimate in the future. As one key study noted,

... the key point about state crime in liberal democracies is that it is not aberrant or anomalous, and has no clear boundaries, but shades imperceptibly into the routine, "legitimate" activities of the state. (Green and Ward 2000: 103)

In such a context, as they explain, emergency ". . . has become the norm" and is used to justify human rights abuses that would not "normally" be viewed as acceptable (Green and Ward 2000). Grewcock has shown similar processes of normalization of state crime, visible in what has been termed the "Australian solution" of externalized border controls. Since the late 1990s, Australian Immigration Services have been training EU border agencies in how to achieve this goal, if not legitimately, then at least legally (Grewcock 2010; Hintjens and Jarman 2003). Also since the 1990s, the Australian government has paid selected governments in the Global South to detain, apprehend and even forcibly deport those considered undesirable migrants, such as failed asylum seekers, and those criminalized as "illegal" (Mountz and Loyd 2013). What Frances Webber (2017) recently coined "Europe's Unknown War", is here termed the EU's Proxy War. Michael Grewcock (2010) has termed this, in another setting, “Australia's 'War' on Illicit Migrants". Webber and Grewcock's formulations bear a close resemblance to ours and reassure us that our interpretation of deterrence policies as a form of warfare, through externalized policies that we define as both proxy war and forms of state crime by proxy are not exaggerated (Grewcock 2010; Webber 2017). When an earlier version of this article was presented in 2015, we were advised to replace "proxy war" with less blunt expressions like "externalised violence" or "violent containment". However, we remain convinced that this proxy war needs to be named for what it is, a war waged for decades, which has only quite recently become visible to wider EU publics and which, prior to 2015, was largely "out of sight, out of mind". 
When the EU's deal with Turkey was signed in 2016, 6 billion Euros were promised, of which around 3 billion Euros had been paid to the Turkish government by the end of 2017, ostensibly so that half a million Syrian children could attend school. "Within weeks, irregular migration dropped to pre-crisis levels demonstrating that Turkey had the capacity to control its western sea borders" (Düvell 2018: 229). Logically, therefore, Turkey could also open its borders and allow refugees back into Greece and the EU. In exchange for Turkey accepting Syrians deported from Greece, the EU removed most visa restrictions on Turkish nationals and agreed to revisit future Turkish-EU membership. The core of the deal was to regularize mass forced returns of Syrians and non-Syrian refugees and migrants to Turkey. This rested on the claim that Turkey was a "safe" third country of temporary settlement for the refugees. The surge in Turkish state violence against minorities in 2017 and 2018, which we present in more detail in a later section of this article, challenges the claim that Turkey was a safe country in the first place. The EU has stood by in the face of arrests of political opposition and innocent bystanders, Kurdish communities, social movement activists, academics and other independent social forces in Turkey. For such reasons, the EU deal with Turkey has been widely criticized. Yet, this deal is very much in line with the proxy war, which now spans a wide inter-regional arc far beyond the southern and eastern perimeters of the EU and has been waged for decades.

The EU proxy war on refugees and migrants has produced many avoidable casualties, though there are no means to determine precisely how many people die annually as a result of the proxy war. Migrant and refugee deaths are not officially recorded by any state or private agency, and the rough estimates available to us are based almost entirely on media reports, collected by a number of NGOs and independent researchers (Edkins 2016; Grant 2011). One study explains that "As a result of the paucity of official statistics, UNITED's List of Deaths and the Fortress Europe blog . . remained the primary sources of data on border-related deaths in the Mediterranean" (Last and Spijkerbroek 2015: 96). The UNITED list is the longest established and has most recently been discussed in The Guardian but only concerns deaths inside and around the immediate borders of European territories (McIntyre and Rice-Oxley 2018). As of 5 May 2018, the list had recorded 34,361 deaths - some identified and some not - since counting started in 1993. This list was of all murders and deaths in transit and all deaths and suicides of asylum seekers, refugees and undocumented people who had already arrived in the EU and Switzerland. One early entry for 1993 notes that a Turkish man of 43 years set himself on fire and died in Croydon Immigration office in the UK on 16 March 1993. Cross-Mediterranean deaths are also included in the list. ${ }^{1}$ Unfortunately, no similarly detailed list of deaths exists for those who die on their way to the EU, for instance in Libya, Albania, Turkey, Egypt, Morocco or Chad. 
Instead, we have IOM estimates of deaths, of the IOM, which tend to be more conservative and focus on the Mediterranean. According to IOM, in 2015, 5,350 migrants died in the Mediterranean compared with 5,146 in 2016 and 3,119 in 2017 (IOM 2018). In the very first month of 2018, the death toll was nearly 343 , in spite of winter weather that usually restricts the number of sea crossings. These numbers do not include those who died or were killed in the Sahara, or on the journey trying to reach the point where they crossed by sea to Europe.

If the battlefront is human beings moving, then the deaths annually recorded in this proxy war are well above the PRIO/Uppsala conflict database's threshold for war, which is "(a)t least 1000 battle-related deaths in one calendar year" (UCDP website n.d.). Yet, migrant and refugee deaths are not recorded in any of the major war and conflict databases collected by scholars in Northern European universities (e.g. PRIO in Oslo, Uppsala and Heidelberg). This is despite evidence, according to Richard Danziger, IOM Director for West and Central Africa, for example, that the number who die en route, for example, in the Sahara are ". . . at least double those who die in the Mediterranean. But we really have no evidence of that, it's just an assumption. We just don't know" (Miles and Nebehay 2017).

What is quite apparent is that most such deaths are quite avoidable and predictable. They result mainly from the direct and indirect forms of violence visited upon the bodies of migrants and refugees, whether at sea, in deserts, in detention centres or in Libya's illegal prisons and slave markets. Weber and Pickering (2011) put this in starkly simple terms:

We argue that people die because of the ways in which the borders between the Global North and the Global South are controlled. These deaths are often foreseeable and can occur by deliberate act or omission. (1)

Through outsourced proxy warfare, a one-sided form of state-sanctioned violence frames EU states themselves, and their borders, as vulnerable entities to be protected from the threatening bodies of the migrants and refugees (Mitzen 2018). Those who die in the Sahara or whilst crossing the Aegean or Mediterranean are as much victims of a proxy war as those who are killed in Ukraine and in Syria as foreign-backed forces battle it out with one another, all proxies for external actors who prefer to remain invisible.

\section{Proxy War $=$ Deterrence + Containment}

Drawing on the work of Mark Duffield, we suggest that a proxy war is being fought over refugees and migrants moving towards the EU. The proxies are other states, such as Libya, Morocco, Turkey and other EU partners further afield, such 
as South Africa or Nigeria. Underpinning the proxy war is a twin logic. The first element of deterrence, already discussed at the start of this article, is combined with the element of containment (Duffield 2007). Both operate according to militarized and spatially colonial principles since specific categories of human beings are excluded from protection and are confined forcibly to certain spaces considered "suitable" for them. Deterrence and containment combine direct and indirect violence, laws and media and public perceptions of threat. Direct violence mostly takes the form of the potentially lethal use of force to detain and expel migrants and refugees back across borders. Indirect violence can be even more lethal and results in hunger, neglect, robbery and diseases, all of which can be fatal for those stranded and immobilized, contained.

Deterrence and containment are like a pincer movement around migrants who become illegalized (Last and Spijkerbroek 2015) through an "illegality industry" that operates well beyond EU borders (Andersson 2012). Through this process of being placed outside the law, most refugees find themselves confined to often hostile and nervous neighbouring countries in their home regions. Those who decide to move on are forced to embark on dangerous and sometimes deadly journeys, across the EU-African or Turkish-EU regions, towards what seem to be safer zones and countries. Crossing borders through maritime waters and deserts, refugees are more vulnerable at each successive stage of their harrowing journeys as they hand over more and more money to move. These journeys have been depicted in a number of films, where they can be represented as forms of resistance to border policing and screening out of certain kinds of human beings through deportations and refusals of asylum (Hintjens 2016; Palladino and Gjergji 2016). At this level, Europe "functions as a scale whose construction holds dire material consequences for those embarking on often perilous journeys to move from one place in the region to another" (Mountz and Loyd 2013: 177).

Since Western Europe is still much safer than Syria, or Turkey, even violencethrough proxy war - may increase the pressure to leave Turkey or Libya and move on to the EU to escape violence. Deterrence through proxy war may add pressure on refugees to flee danger along the route and continue their journeys in the hope of finding less "hostile environments". Those who travel involuntarily will not be easily deterred since lethal violence is their main "push" factor. Outright proxy warfare against potential refugees - as in Turkey's border region with Syria today or as previously in Libya - will tend to produce "backwash" effects by generating more rather than less pressure on those in transit to move on. The EU has a limited capacity to enforce exclusion from its own borders through violent means, without the support of proxy states. And yet containment will become more contested through law, the more violently it is imposed and policed. 
The outer perimeter of the EU's Schengen zone can never be sealed against all newcomers except by locking inside all those who one day hope to become regularized, get nationality and travel. As Eurosur partners continue to wage proxy war against "illegal" human migration through policing of their Southern borders and territorial waters, bona fide refugees are pushed back (Andersson 2012; Weber and Pickering 2011). In Libya, for example, mistreatment of refugees and migrants started well before the end of Ghaddafi's regime. In 2007, a treaty was cynically

Signed by former Libyan dictator Gaddafi and Italy's prime minister Berlusconi in a tent near Benghazi . . . [and] presented as a turning point in the shared colonial history of Italy and Libya. Berlusconi's solemn apology for Italy's colonial enterprise in the early twentieth century allegedly marked the beginning of a new course. (Palladino and Gjergji 2016: 3)

Apart from Germany, EU member states have shown more concern to avoid responsibility for refugees than to protect them. In a bizarre show of bravado, some EU politicians appear to be competing with one another to present an "inhuman" face to their domestic electorates. Refugee status, if granted to the handful who make it to that stage, is almost always temporary. Refugee status can be revoked if the home country is judged (often wrongly) as "safe to return to". Even if today the refugee camps of Kenya, Bangladesh or Jordan were closed by force, renewed warfare over water and other resources would push up refugee numbers in future, and worldwide. Having abandoned their short-lived belief in human rights as guidelines for actions and policies, EU member states appear to be abandoning even the foundation of the EU's existence, namely, the shared desire for peace. EU heavy industries remain to serve powerfully militaristic ends, and peaceful economic development is as distant a prospect in Europe today as it is in the US. Reflecting on the EU as a zone of (in)security, Mitzen (2018) comments that

... the EU's distinctiveness as an actor on the world stage is due in large part to its success at producing its long peace. But the mechanisms producing that peace are primitive modes of anxiety management. (394)

The neglect of rescue at sea, and expulsions that result in predictable deaths, for instance, may come to be seen as forms of war crimes, and certainly as criminal acts that violate both the Law of the Seas and the Refugee Convention, which explicitly rules out judging a refugee for not having the correct papers. According to the courts, pushbacks in The Mediterranean violated this ban. In light of the Hirsi Jamaa case and other similar rulings, EU governments should start to acknowledge that their security operations under FRONTEX, for example, are more like 
failed military operations than legitimate and legal border control measures (Palladino and Gjergji 2016). None of the many acts of individual and group violence that make up the proxy war do anything to solve the original problems that force people to leave their countries, including civil wars and environmentalinsecurities that produce refugees and forced migrants in the first place.

Ironically, before 2015, EU member states agreed to prevent such expulsion of refugees prior to hearing their asylum claims. In their haste to blame smugglers for rising refugee arrivals, however, and in the euphoria of the new proxy war being fought by Turkey, the EU Asylum Procedures Directive (APD) of 21 June 2015 was forgotten. The APD asserted the right of non-refoulement (non-return) and proposed that it should be robustly defended for all those claiming asylum, anywhere in the EU. Article 6 of the APD provided that asylum claims had to be registered at the first opportunity, in any EU state. Article 8 states,

\footnotetext{
... training must be provided to officials who may come into contact with persons seeking international protection (in particular during the surveillance of land or maritime borders or during border checks) so that they are able, inter alia, to provide information on where and how an application can be lodged.
}

Most officials who meet undocumented migrants either are not trained in these provisions or are trained not to let asylum applicants know their rights in this way. The APD which was so sorely needed in 2015, and appeared all but forgotten in the rush to prevent migrants from arriving by land and sea at Europe's borders.

\section{EU Migrant Crisis: The Proxy War Made Visible}

With the crisis of irregular migration intensifying in 2014 and 2015, EU member states' proxy war on refugees gradually came into the daylight, becoming more visible. As thousands died at sea, especially in the Eastern Mediterranean, most from countries at war, especially Syria, Eritrea and Afghanistan, these preventable deaths of "innocent families" started to be blamed on smugglers and traffickers. Draconian EU immigration policies, rooted in deterrence principles, tried to control the flight of people out of war-torn Somalia, Iraq, the Democratic Republic of the Congo (DRC), Afghanistan, Eritrea and Syria. As they travelled the routes that passed through Turkey, Libya, Morocco, the Caucuses, Eastern Europe and even Russia, the passage of refugees was violently blocked off, with walls, with policing and with other physical and legal barriers.

A particularly cynical example of proxy war on irregular migrants followed the 2008 Benghazi Accords between Libya, Italy, the EU and the North Atlantic Treaty Organization (NATO). Under this agreement, the Italian government would 
compensate the Libyan government for damage done to Libya by Italy during the Fascist military occupation of the inter-war and war years. In return, Ghaddafi's regime would "get tough" with those defined as illegal migrants, fleeing through Libya to Europe:

Italy promised to help start development projects in Libya and the countries of origin of irregular immigration with EU funds while Libya was to reach agreements with these same countries to reduce irregular migration and to accept the repatriation of migrants. (Pace 2013:13)

This agreement prefigured the EU-Turkey deal some years later, and both sets of agreements between the EU and its partners showed the same disregard for human rights norms, especially for non-refoulement principles, core to the 1951 Refugee Convention. Soon both Libya and Italy started to forcibly deport thousands of Africans south, including into the Saharan desert. Even those with refugee status, who had filed bona fide asylum claims with the Office of the United Nations High Commissioner for Refugees (UNHCR), were not immune from such massexpulsions.

What is now the worst refugee crisis since the Second World War has not been helped by the proxy war the EU has been waging beyond its external borders. Refugee and migrant exclusion is contracted out, at the very time the UNHCR warns that its revenue is insufficient to cover basic food needs in many refugee camps, especially in the Middle East region. There were more than 65 million people in flight in 2017, a situation worsened by the growing exclusionary and even racist policies of the wealthiest states on the planet, including the US, Gulf states and EU member states moving to the right. As UNHCR data shows, those who flee to Europe are a very tiny fraction of all those forced to remain for years, or decades, in neighbouring countries (UNHCR 2018). Jordan, Pakistan, Kenya, Sudan or Tanzania, all host refugee camps where refugees live for years, or even generations. In those camps, they face deadly diseases, sexual and personal violence and only the occasional flicker of hope of third country resettlement. What Greek islands such as Lesbos experienced in the summer of 2015 and 2016 was a fraction of the mass movement into refugee camps of Kenya, Jordan and Turkey, for example. Yet European public opinion was shocked and the Greek state was completely unable to cope, even once humanitarian agencies came on board. The refugee crisis was as much a crisis of refugee reception as anything else. Yet hostile EU responses to Syrian refugees start to make sense when set against the steady drip-drip-drip of the longstanding proxy war fought against refugees and migrants for decades already.

Writing in the South Atlantic Quarterly more than a decade ago, Erik Cazdyn (2007) suggested that capitalism, red in tooth and claw, has a tendency to eat its own children, as the opening quotation of this article suggests. After many years 
of external military intervention, regime collapse, torture, massacres and assassinations, the increased use of violence against civilians to resolve disputes in Iraq, Libya, Somalia and also in Yemen, the DRC and Syria is not really unexpected. With Turkey's attacks on Kurds in Turkey and Syria, EU member states are now finally confronting the possibilities of war spilling over into EU territory, in a way not seen since the break-up of the former Yugoslavia in the early to mid-1990s. Rising refugee movements are also a barometer of the inability of proxy war to offer longer term solutions or ways out of this crisis that has been created. At best a proxy war, even on its own brutal terms, can only shift refugees from here to there but cannot prevent their movements altogether. Such stop-gap measures do not even start to address why so many are on the move, fleeing war, persecution and hopelessness.

\section{The Turkish Warrior State and the EU Proxy War}

In January 2018, Turkish ground troops rolled into Afrin, a Kurdish enclave in northern Syria, claiming they needed to create a "safe zone" for security purposes, in a military operation that ironically was called Operation Olive Branch by Ankara (Bilginsoy 2018). Turkish Army Forces and Free Syrian Army troops, supported by an air campaign, sought to oust fighters from the Kurdish People's Protection Units (YPG) in and around Afrin. The Turkish President Erdoğan claimed that once a "safe zone" was created, they would be able to send home to Syria some of the 3.5 million Syrians confined to Turkey by the EU's refusal to allow them admissions. All this was done in the name of "European security", highlighting how proxy war structures the EU's relations with its neighbours.

In its recent rhetoric, Turkey has presented itself as useful to Europe's security and even as indispensable. As Turkey drifts away from its post-Cold War rapprochement with Russia and the Middle Eastern states, a worrying trend has emerged. The latest attacks on Kurdish areas inside Syria appear to mark a return to the security-driven logic that was dominant during the bad old days of the Cold War. Now as then, it seems that close allies of the West can do no wrong. And it seems that the Turkish regime fully expects the West, if not to approve, then at least to ignore its military campaign. Framed as part of a wider anti-terrorism strategy in the region, Kurdish forces have been targeted in spite of their pivotal role in defeating the Islamic State forces. Turkey's President Recep Tayyip Erdoğan, suggests that Turkey can help the EU's wider fight against terrorism by stopping onward irregular migration from Syria, constructing a wall at the Syrian border to this end. The logic of warfare has been turned against the EU as friendsof-convenience, but it has been turned much more lethally against the Kurds. The EU is now caught in paying for Turkey to fight its "dirty war" against those who 
are potential refugees. At the same time, Turkey is settling old scores, in full view of the international community, with its own Kurdish minority, and waging its own war against the so-called Kurdish "terrorists" in Syria.

The 2018 attacks were not the first time Erdoğan's regime used Syrian refugees as bargaining chips in their negotiations with the EU. After peace negotiations between the government of Turkey and the Kurdish movement collapsed in 2015-2016, the Turkish Armed Forces launched their own military "clean up" operations in southeast Turkey against the Kurdistan Workers' Party (PKK). At the same time, this military campaign targeted the Kurdish Democratic Union Party, part of the opposition linked to the PKK. The UN High Commissioner for Human Rights reported that more than 2,000 civilians were killed in this campaign, and 355,000 became Internally Displaced Persons (IDPs) within Turkey (Office of the United Nations High Commissioner for Human Rights 2017). Several towns, including the historic city of Sur, were wiped off the map.

In seeking to deflect criticism from Europe, the Turkish regime played on the role of Turkey in stopping migration towards the EU. The March 2016 EU-Turkey refugee deal cost the EU some $€ 6$ billion, pledged to Turkey for helping keep Syrians in Turkey (Isik 2016). Under this deal, irregular migrants arriving in the EU from Turkey were to be returned - and Turkey would police its shores to keep them in. Journalists and academics tried to expose the atrocities against Kurdish civilians, and how they had been profiled as "terrorists" by the regime. However, when they wrote of such things, these journalists and academic too were targeted by Turkish authorities and paid a heavy price. ${ }^{2}$

The deal was similar to that of Italy and Libya, but on a much grander scale. The temptation of the authoritarian regime to "release" refugees in the case of conflict of interests with the EU was also similar to Ghaddafi's decision, at the start of the Libya war, to release African migrants from detention and force them into boats across the Mediterranean. After Egypt, Libya and Morocco, Turkey is the latest country to fully embrace its position as the EU's external border guard, fighting its proxy war. The regime realizes that migrants contained in Turkey will be useful to further Turkish interests domestically as well as in its international relations and negotiations over EU membership.

Meanwhile, EU member states like Italy, in the case of Libya, have been willing to violate their own widely proclaimed human rights norms and to channel funds to an authoritarian government that continues to oppress its own people. In Turkey, the stakes are as high as in Libya, or higher, since in carrying out an asymmetrical war against Kurds both in Turkey and in Syria, the government holds Syrian refugees as bargaining chips. If EU criticism becomes too strong, Erdoğan has repeatedly threatened to "release" (i.e. force) Syrian refugees back into Europe. The Turkish government's return to Cold War logic has been made 
possible by the proxy war that in practice has reinforced concentric rings of exclusionary policies towards migrants, around the EU for decades.

\section{The Political Price of Proxy War}

Erdoğan has played the refugee card repeatedly since the deal in 2016. In November that year, for example, when the European Parliament voted to freeze negotiations on Turkey joining the EU following military attacks on Kurdish areas, he threatened to unleash refugees on Europe in revenge (McKernan 2016). Playing on the fears of the EU, which wants Syrian refugees kept out, the Turkish President threatened "if you go any further, these border gates will be opened" (Karadeniz and Tattersall 2016). Having called for an end to Turkey's accession talks, the European Parliament was objecting to human rights abuses against opposition inside Turkey; the response was to warn of the end of Turkish "goodwill" in containing refugees on its territory. As well as threatening that Syrians will be allowed to leave Turkey, thus "insecuring" an already uncertain Europe (Mitzen 2018), Erdoğan has also used his Twitter account to explain to anyone interested, that military attacks on Afrin inside Syrian territory are also for the benefit of the EU.

Unfortunately, the EU member states now seem trapped in a logic of their own making, complicit with war crimes and human rights abuses inside Turkey, committed ostensibly for EU security purposes. In January 2018, a Brussels representative of the ruling Turkish Justice and Development Party explained, when he said of the military attacks, "The operation will lead to the return of Syrian refugees in Turkey. The fewer refugees in Turkey, the less migrant flow to Europe" (AA 2018). It is now being claimed that by "clearing out" Kurdish enclaves, the Turkish state can "ensure the safe return of displaced Syrians to their homes" and in the long term "curb the flow of terrorist elements and undocumented migrants into Europe" (as though they were one and the same thing; Ahmet Aytaç 2018). It was claimed by the Turkish government that eventually Operation Olive Branch would allow "500,000 refugees to return to Afrin" (Ahmet Aytaç 2018).

In light of such reassurances that military force would mean fewer refugees coming to Europe, the almost total silence of EU leaders and member states about Turkey's military attacks on Afrin, speaks volumes about their complicity. Given that the perception of being under threat by "illegal migrants" and "terrorists" is shared by the Turkish government and EU member states, the differences between them are less in their world views and more in strategy and self-interest. Defined in 2003, the premise of the European Security Strategy remains one of "its own security as being under threat from 'illegal migrants' and terrorism” (EU 2003). Turkey's military operation in Syria against the Kurdish autonomous region which is a threat to Turkey itself - will also help Europe address its own threat. 
The news outlet of a pro-regime think-tank, SETA, recently put this in plain terms: "If Europe and the EU want to protect their own values, then they should support Turkey's operation” (The New Turkey 2018). As the 2003 EU Security Strategy already envisaged,

The integration of acceding states increases our security but also brings the EU closer to troubled areas. Our task is to promote a ring of well governed countries to the East of the European Union and on the borders of the Mediterranean with whom we can enjoy close and cooperative relations. (8)

This then is the paradoxical consequence of the proxy war on refugees - not a safer Europe, but an EU more vulnerable to manipulation by the national interests of its closest partners in the proxy war. Turkey in particular - as previously did Libya - positioned itself as Europe's indispensable security provider. This carries heightened risks for EU member states who may in future find themselves in court for complicity in human rights abuses and war crimes by the Turkish state. Whilst pursuing its own divide-and-rule policies to entrench itself politically, the current Turkish regime has started attacking Kurdish civilians and anti-ISIS fighters and knows it can do so almost with impunity so long as its EU allies depend on it not to "release refugees" back into the EU. In this way, the EU itself is no longer a "safe zone" towards which Syrians and other refugees can move to find safety through Turkey. Once more, as happened in the Balkans decades ago, the EU has become complicit in the corralling and containment of vulnerable refugees into walled, militarized and ethnically cleansed zones.

Meanwhile with countries further afield, the EU member states forge "agreements" to accept returned irregular migrants, most of whom applied for asylum and who have been routinely rejected by the "culture of disbelief" operating in asylum institutions across the EU. This is a less visible part of the proxy war - the forced deportation of tens of thousands of people back to war zones like Afghanistan. Whether from Syria, Iraq or sub-Saharan Africa, all are being forced back, deported from the EU (Anderson et al. 2013). Webber (2017) describes arrangements between the EU and Afghanistan in the following terms:

The Afghanistan deal . . commits the Afghan government to take back its own nationals. It is one of eighteen "non-standard arrangements" for readmission and returns which the EU has made since 2008 - eight of which were agreed in 2016. (39)

In this way, using proxy states to effectively wage war on civilians, the EU and its member states try to distance themselves from the "dirty work" of forcibly returning those vulnerable to human rights abuses to unsafe places. They wash their 
hands of the asylum seekers they have rejected, and return them to the very governments that they fear, to face their fate. Their deaths too are uncounted but need to be added to the casualties of this multi-dimensional proxy war. EU states pressure governments and embassies to issue papers, then take no responsibility for the outcomes when a person returned is arrested, tortured or killed.

Seeking to "immunize themselves from legal responsibility for deterrence" (Hathaway and Gammeltoft-Hansen 2014: 9) may not prove possible in the longer term for the EU and its member states. Continuing to outsource violence and wage proxy war against refugees may even expose EU member states, and the EU, to substantial risks of future legal prosecution. In 2012, for example, the European Court of Human Rights finally ruled that the agreement between Italy and Libya contravened Article 3 of the European Convention on Human Rights. "In 2009 alone (according to Human Rights Watch and UNHCR), Italy carried out nine pushback operations on the high seas, returning 843 Somali, Eritrean and Nigerian nationals to Libya", which is refoulement, illegal under international refugee law (quote from Palladino and Gjergji 2016: 4). The court noted that Somalis and Eritreans were particularly targeted in these operations by Italy, the former colonizing state (Kirchgaessner and Tondo 2018). Yet, a few months after this ruling, Libya was receiving indirect support from Italy again to run its migrant detention centres in Tripoli and other main cities.

The prospects are that prosecutions of EU actors responsible for financing the proxy war on refugees will continue. Those governments and companies that sell arms and border surveillance systems to partners well beyond the EU borders may now risk being accused of facilitating repressive border controls. Operating through private companies, rather than as state actors, has been one way to try and avoid legal consequences.

\section{Ending EU States' Impunity for Violent Deaths}

The EU claims to have a proud record of respect for human rights and humanitarian principles. Yet, the European Commission's Humanitarian Aid and Civil Protection Office (ECHO) and other EU institutions seem to find it quite acceptable to finance institutions like FRONTEX to engage in military policing of EU waters. Meanwhile, the EU's own Guidelines on the funding of humanitarian protection specify that member states' "primary responsibility" is to protect people living under their jurisdiction. In situations of armed conflict, all parties, including non-state actors, who control a territory and conduct military operations, hold formal legal protection responsibilities for the people within their territory. This is also true of those fighting the proxy war against refugees on the EU's behalf. The first step EU member states could take is to reassert claims that human rights are part of the cultural and historical legacy of EU member states (Bilgic 2013). 
Italy has found itself in court for its direct intervention in this particular locality of the proxy war on migrants. Sometimes, the EU's proxy war on refugees has even targeted the humanitarian agencies that seek to help rescue refugees and otherwise protect them. In August 2017, Libyan coast guards shot at NGO boats that were rescuing migrants from the sea off the Libyan coast, leading these agencies to temporarily put an end to their humanitarian operations (Henley and Giuffrida 2017).

The case of Hirsi Jamaa and others v. Italy in 2012, where the European Court of Human Rights (ECtHR) ruled against Italy, was very significant in this respect. Having pushed back a group of Eritrean irregular migrants to Libya, the Italian government claimed this was permitted under the bi-lateral Benghazi Accords between the two countries. However the court ruled that Italy's action was in direct violation of Protocol 4 of the European Convention of Human Rights, which had legal precedence over the Benghazi Accords. This protocol defines and bans "collective expulsion"; Italy was guilty.

Partner countries of the EU like Morocco, Turkey, Kenya or Nigeria should also know that if they are involved in acts of violence against those who may be refugees and need protection, even if it is on behalf of the EU, and with EU funding and training, they may also become legally liable for these human rights violations, which could amount to "war crimes". As Schmitt and Vihul (2014: 57-58) suggest,

... customaryinternationallaw . . capturedbythe International Law Commission in its Draft Articles on Responsibility of States for Internationally Wrongful Acts, states are responsible for their "internationally wrongful acts" to those whom they have "injured" in the sense of violating an obligation owed.

Those they have injured include refugees "contained" for years in camps and prisons in the Global South, and only a handful need to connect with international human rights lawyers, to sue the EU member states that were supposed to protect them, and instead fought them through their proxies.

Right now, EU development cooperation is paying, so that refugees outside the EU will be hounded rather than helped or protected. In the name of extraterritorial border controls, human rights are violated by EU partner countries, on the EU's behalf. Under the Refugee Convention, the cornerstone principle is nonréfoulement, which requires not sending people back across the border if they wish to claim asylum. This principle is being violated routinely. The EU deal with Turkey, agreed in 2016, involves summary deportations from Greece, and clearly violates non-réfoulement. Somehow, at the same time,

Turkey was declared a "safe third country" for refugees, despite failing to meet the criteria for such a designation in the EU's own Asylum Procedures Directive, 
not least by virtue of its geographical reservation to the 1951 RefugeeConvention which means that no non-European refugees are officially recognized. (Webber 2017: 41)

"Swapping" new admissions of those already granted refugee status outside the EU, with forced returns to Turkey, is a numbers game that fits within the logic of the proxy war being fought on refugees and reflects the grim realities for refugees of being caught up in a deterrence-based immigration system (Hintjens et al. 2011).

Under the 2002 EU Directive and Framework Decision on "Strengthening the penal framework to prevent the facilitation of unauthorised entry, transit and residence", member states should set up measures to prosecute those who help those with irregular status. Despite such threats, there are many lawyers, social workers, teachers, academics, ordinary community members, neighbours and even MPs who reject deterrence. As Liz Fekete has convincingly demonstrated, attacks on traffickers and smuggling may be a fairly transparent pretext for creeping criminalization of solidarity with refugees and migrants (Fekete 2009). "People who help" failed asylum seekers can find themselves prosecuted, even when they are family members. The father, Abdallah, of drowned toddler, Alan Kurdi, was even accused in absentia, in a Turkish court, of being a smuggler since he was the one who had arranged for the boat that would carry his wife and sons to Greece, a boat which later sank (Middle East Eye 2016). Increasingly, neighbours, urban residents, professional advocates such as lawyers, and doctors or social workers are being arrested for helping undocumented people in particular. There are a lot of people in EU publics keen to work with refugees, whether in Calais, Lesbos or Lampedusa. Whereas we suggest in the rest of this section that the clock is ticking for states to be held accountable, at present, it is mainly NGOs and individuals that seek to help refugees that are most vulnerable to prosecution.

Even by rescuing people at sea, one can be accused of assisting or facilitating the unauthorized transit or residence of someone who lacks authorization; one is redefined as a smuggler. Among those who found themselves arrested in France were those citizens who supported refugees stuck in the Calais "Jungle".

The more hopeful aspect of all this is that the rapidly transforming situation in Europe will not only provoke racism, as was most evidently the case between 2015 and 2016, but also a tide of reactions against state impunity for the war on refugees. In 2015, some EU citizens opened their homes to refugee families, in Italy, Greece, the UK, France and the Netherlands. Even in Iceland, refugees were welcomed. Some local publics seem to better understand the fundamental principles of Article 31 of the 1951 Geneva Convention than governments, namely that refugees cannot come with the "proper papers" from the places they flee. General immigration controls should not therefore apply to refugees. Article 31 also 
explicitly states that penalties cannot be imposed on those forced to enter without the proper documents, if the reason they enter is to claim asylum.

As the proxy war on refugees became more visible, in the course of 2015, more people in the EU started to understand immigration controls for what they have become - a kind of battle, fought on many fronts. Protests arose against collaboration with authoritarian regimes that abused the rights of their own civilians and refugees alike, such as Erdoğan in Turkey and warlords in Libya. As Frances Webber (2017) states,

The EU's outsourcing of migration controls to the war-torn, violent failed state of Libya was widely condemned. Seventy national and international NGOs wrote an open letter to EU heads of state and leaders, arguing that it would expose people to ill-treatment and arbitrary detention. (44)

So is the worm finally turning? Several recent reports, including one funded by the Carnegie Trust, another commissioned by the Dutch government and reports from "respectable" human rights organizations, conclude that perhaps the key single determinant of smuggling at sea, and the deaths that result from dangerous transport, especially across the Mediterranean, is the closing down of legal options for air travel and entry to Europe, and the restrictive visa policies practised by EU member states. Even the usually very moderate IOM agreed with this prognosis in a 2014 report entitled Fatal Journeys: Tracking Lives Lost during Migration, and they might have added: during flight (IOM 2014).

Hein de Haas, migration expert at both Oxford University and Maastricht University, tried to explain, in the summer of 2015, that human smugglers did not create illegal migration - they only responded to restrictions on legal migration by governments. He argues that when circular patterns of migration are broken, problems result. Interviewed by the media, he responds that "The real crisis is European impotence to respond, and it would be outrageous if Europe can't cope with that when the vast majority of refugees are in much poorer countries like Lebanon, Jordan and Turkey" (Robins-Early 2015). The failure to respond (or protect), suggests de Haas, is the main problem among European Union member states.

\section{Concluding Thoughts}

Even if the EU proxy war continues indefinitely, it will not achieve its stated aim of making EU citizens - and EU states - feel safer. From the crisis of 2015 onwards, as the EU proxy war against refugees' and migrants' bodies became more visible, the need to end it and make progress became more obvious. What this article has suggested is that this form of warfare, waged through proxy states 
and security agencies, has not only undermined collective EU claims to legitimacy but, by violating shared democratic and human rights norms, exposes EU states to charges of state crimes against refugees. Furthermore, we conclude by noting the way that abuses of the rights of refugees have a tendency to "ricochet", undermining citizenship rights within the EU as well. As Pickering asks, ". . . what are the consequences of policing, deterring and punishing asylum seekers?" (Pickering 2005: 8). In answer to this, it can be pointed out that "the concept of legitimacy provides the link between state deviance and human rights" and is the ultimate test of whether states like EU member states can be held accountable for the crimes they may commit, in this case against refugees and asylum seekers (quote from Green and Ward 2000: 108). As Mitzen (2018) reminds us, efforts to unite to police the external borders could be self-defeating since among EU member states

... the cultural repertoire in security affairs consists of primitive modes of political reaction: othering, stigmization, securitisation of subjectivity. If we look closer at them we may see that they actually frustrate the realisation of the EU's normative power. (395)

The proxy war involves EU member states funding and promoting "security solutions" that "contain" and "deter" migrants along the migration route, but which violate international law, which is the foundation of the EU's special claim to constitute a privileged liberal democratic space. This spatial projection of state violence from the EU outwards, through the compliance of its "client states", has done deep damage both to the rights of refugees and to the EU's collective reputation as a zone where human rights are protected.

If EU member states and institutions were at all serious about addressing the root causes of refugee flight, they would start by providing more consistent, solid financial support for UNHCR refugee protection activities close to countries that produce the most refugees, such as Yemen, Syria and Sudan (UNHCR Syria 2018). After all, EU member states and EU institutions could be held legally liable for deaths that have resulted from the proxy war as an aggressive and illegal war. Responsibility cannot be avoided for very long; although "the concepts of 'acting on the instructions' and 'acting under the direction or control' of a state have not been well-developed in the law of state responsibility" (Schmitt and Vihul 2014: 61 ), in future this can change.

A radical overhaul is needed of EU asylum and visa policies, and starts with recognition that deterrence-based border controls are both unjust and unworkable. To regain some kind of moral capital, the EU would need to craft policies more in line with human rights and humanitarian law. This could prove a more workable basis for inter-EU cooperation than the common enemy of a fictitious migrant threat. 
Damage done to the EU's reputation as a zone of peace, democracy and human rights may perhaps be repaired in time. Meanwhile, as a first step, the EU's own Asylum Procedure Directive, discussed earlier in this article, should be respected by member states and collectively implemented. Otherwise, the EU and its member states lose any claim to embody and defend human rights principles at all. It does seem that for some, the hardest part of the proxy war will be ending it.

By seeking to "deter", "halt" and "repel" human movement, the EU and its member states seem to have embarked on a war they can only lose, and this is for two reasons. First of all, they make themselves vulnerable to prosecution for state crimes since "international law has been accepted as law by most nations of the world", with the consequences that "violations of these laws are criminal wrongs under the existing international legal order" (Kramer and Michalowski 2005: 447). Secondly, however much development aid is spent and however powerfully military and external security solutions are projected beyond EU borders, counterintuitively, the proxy war seems to actually reinforce pressures on refugees to move as rapidly as they can, in spite of the enormous risks involved in doing so, towards the EU.

\section{Notes}

1. The full details of each case and source of each report are meticulously recorded in UNITED's list, still regularly updated on https://uploads.guim.co.uk/2018/06/19/TheList.pdf (up to 5 May 2018), which is sobering reading for those not yet aware of the war inside Europe against refugees, let alone the remote control proxy war.

2. See https://theconversation.com/turkeys-academics-pay-heavy-price-for-resisting-erdogans-militarisedpolitics-54088.

\section{References}

AA. (2018) “Anadolu Ajenci, Zeytin Dali Harekati 'Zeytin Dalı Harekatı Avrupa'nın güvenliğine katkı sağlayabilir'”. Available online at http://aa.com.tr/tr/turkiye/zeytin-dali-harekati-avrupaninguvenligine-katki-saglayabilir/1040712.

Ahmet Aytaç, S. (2018) “Turkey’s Operation Olive Branch: 10 Questions Answered”, Anadolu Agency News, 26 January. Available online at http://aa.com.tr/en/middle-east/turkeys-operationolive-branch-10-questions-answered/1043667.

Anderson, B., Gibney, M. and Paoletti, E. (2013) The Social, Political and Historical Contours of Deportation. New York: Springer.

Andersson, R. (2012) “A Game of Risk: Boat Migration and the Business of Bordering Europe", Anthropology Today 28(6): 7-11.

Bilgic, A. (2013) Rethinking Security in the Age of Migration. London: Routledge.

Bilginsoy, Z. (2018) “AP Explains: Turkey's 'Operation Olive Branch' in Afrin”, Business Insider, 22 January. Available online at http://uk.businessinsider.com/ap-ap-explains-turkeys-operation-olivebranch-in-afrin-2018-1 ?international $=$ true $\& \mathrm{r}=\mathrm{UK} \& \mathrm{IR}=\mathrm{T}$. 
Boswell, C. (2007) “The Securitisation of Migration: A Risky Strategy for European States”, DIIS Brief, April. Copenhagen: Danish Institute for International Studies.

Cazdyn, E. (2007) “Disaster, Crisis, Revolution”, South Atlantic Quarterly 106(4): 647-662.

Duffield, M. (2007) Development, Security and Unending War: Governing the World of Peoples. Cambridge: Polity Press.

Düvell, F. (2018) “The 2015 Refugee Crisis, EU-Turkey Relations and Migration Diplomacy, 227 230 in William Allen, Bridget Anderson et al. 'Who Counts in Crises? The New Geopolitics of International Migration and Refugee Governance"”, Geopolitics 23(1): 217-243.

Edkins, J. (2016) "Missing Migrants and the Politics of Naming: Names without Bodies, Bodies without Names", Social Research 83(2): 359-389.

European Union. (2003) "European Security Strategy - A Secure Europe in a Better World", 12 December. Available online at https:/europa.eu/globalstrategy/en/european-security-strategysecure-europe-better-world.

Fekete, L. (2009) "Europe: Crimes of Solidarity”, Race \& Class 50(4): 83-97.

Grant, S. (2011) "Recording and Identifying European Frontier Deaths", European Journal of Migration and Law 13(2): 135-156.

Green, P.J. and Ward, T. (2000) "State Crime, Human Rights, and the Limits of Criminology", Social Justice 27(1): 101-115.

Grewcock, M. (2010) Border Crimes: Australia's 'War' on Illicit Migrants. Annandale: Federation Press.

Hathaway, J. and Gammeltoft-Hansen, T. (2014) "Non-Refoulement in a World of Cooperative Deterrence", University of Michigan Law School, Law and Economics Working Papers, 1 August. Available online athttp://repository.law.umich.edu/cgi/viewcontent.cgi?article=1216\&context=law_ econ_current.

Henley, J. and Giuffrida, A. (2017) "Three NGOs Halt Mediterranean Migrant Rescues after Libyan Hostility", The Guardian, 14 August. Available online at https://www.theguardian.com/ world/2017/aug/14/three-ngos-halt-mediterranean-migrant-rescues-after-libyan-hostility.

Hintjens, H. (2016) "Islands and Images of Flight around Europe's Southern Rim: Trouble in Heterotopia”, in L. Mannik, ed., Migration by Boat Discourses of Trauma, Exclusion and Survival, 197-217. Oxford and New York: Berghahn Books.

Hintjens, H. and Jarman, A. (2003) "Acting for Asylum: The Nexus of Pro-refugee Activism in Melbourne", in M. Leach and F. Mansouri, eds, Critical Perspectives on Refugee Policy in Australia, 59-87. Burwood: Deacon University Press.

Hintjens, H., Kumar, R. and Pouri, A. (2011) "Pro-Asylum Advocacy in the EU: Challenging the State of Exception", in T.D. Truong and D. Gasper, eds, Transnational Migration, Development and Human Security, 209-223. Berlin: Springer.

Hughes, G. (2014) “Ukraine: Europe's New Proxy War”, Fletcher Security Review 1(2): 105-108.

IOM. (2014) Fatal Journeys: Tracking Lives Lost during Migration, T. Brian and F. Laszko, eds.

Geneva: International Organization for Migration.

IOM. (2017) “Migrant Deaths and Disappearances: 2016 Analysis”, Issue No. 8, March. Berlin: Global Migration Data Analysis Centre.

IOM. (2018) "Mediterranean Migrant Arrivals Reached 171,635 in 2017; Deaths Reach 3,116", 1 May. Available online at https:/www.iom.int/news/mediterranean-migrant-arrivals-reached171635-2017-deaths-reach-3116.

Isik, E. (2016) "The EU-Turkey Refugee Deal and the Kurdish Issue”, Opinions War \& Conflict, Al Jazeera, 5 March. Available online at http://www.aljazeera.com/indepth/opinion/2016/03/euturkey-refugee-deal-kurdish-issue-160302113254551.html. 
Karadeniz, T. and Tattersall, N. (2016) "Erdogan Warns Europe that Turkey Could Open Migrant

Gates", Reuters, 25 November. Available online at https://www.reuters.com/article/us-turkeyeurope-erdogan/erdogan-warns-europe-that-turkey-could-open-migrant-gates-idUSKBN13K0R6.

Kingsley, P. (2015) "EU Launches Naval Operation to Monitor Libyan People Smugglers", The

Guardian, 22 June. Available online at http://www.theguardian.com/world/2015/jun/22/euannounces-naval-operation-to-monitor-libyan-people-smugglers.

Kirchgaessner, S. and Tondo, L. (2018) “Italy's Deal with Libya to 'Pull Back' Migrants Faces Legal Challenge”, The Guardian, 8 May. Available online at https://www.theguardian.com/world/2018/ may/08/italy-deal-with-libya-pull-back-migrants-faces-legal-challenge-human-rights-violations.

Kramer, R.C. and Michalowski, R.J. (2005) "War, Aggression and State Crime: A Criminological Analysis of the Invasion and Occupation of Iraq", British Journal of Criminology 45: 446-469.

Last, T. and Spijkerbroek, T. (2015) "Tracking Deaths in the Mediterranean: Chapter 3", in T. Brian and F. Laczko, eds, Fatal Journeys: Tracking Lives Lost during Migration, 85-106, International Organization for Migration. Available online at http://thomasspijkerboer.eu/wp-content/ uploads/2015/01/Tracking-Deaths-in-the-Mediterranean.pdf.

Lazaridis, G. and Wadia, K. eds. (2015) The Securitisation of Migration in the EU: Debates Since 9/11. Basingstoke and New York: Palgrave Macmillan.

McIntyre, N. and Rice-Oxley, M. (2018) “It's 34,361 and Rising: How the List Tallies Europe's Migrant Bodycount", The Guardian, 20 June. Available online at https://www.theguardian.com/ world/2018/jun/20/the-list-europe-migrant-bodycount.

McKernan, B. (2016) "European Parliament Votes to Block Turkey's Efforts to Join EU”, The Independent, 24 November. Available online at http://www.independent.co.uk/news/world/ europe/turkey-eu-membership-suspended-negotiations-erdogan-vote-a 7436256.html.

Middle East Eye. (2016) “Turkey tries Father of Refugee Alan Kurdi for his Drowning”, 11 February. Available online at https:/www.middleeasteye.net/news/turkey-tries-father-refugee-alan-kurdihis-drowning

Migreurop. (2007) Guerre aux Migrants: le livre noir de Ceuta et Melilla. Paris: Editions Syllepse.

Miles, T. and Nebehay, S. (2017) "Migrant Deaths in the Sahara Likely Twice Mediterranean TollU.N.”, Reuters, 12 October. Available online at https://uk.reuters.com/article/uk-europe-migrantssahara/migrant-deaths-in-the-sahara-likely-twice-mediterranean-toll-u-n-idUKKBN1CH22D.

Mitzen, J. (2018) “Anxious Community: EU as (in)Security Community”, European Security 27(3): $393-413$.

Mountz, A. and Loyd, J. (2013) "Constructing the Mediterranean Region: Obscuring Violence in the Bordering of Europe's Migration 'Crises"”, ACME: An International E-Journal for Critical Geographies 13(2): 173-195.

Mumford, A. (2013) "Proxy Warfare and the Future of Conflict", The RUSI Journal 158(2): 40-46.

Office of the United Nations High Commissioner for Human Rights. (2017) "Report on the Human Rights Situation in South-East Turkey, July 2015 to December 2016”, February. Available online at http:// www.ohchr.org/Documents/Countries/TR/OHCHR_South-East_TurkeyReport_10March2017.pdf.

Office of the United Nations High Commissioner for Refugees. (2018) "Figures at a Glance". Available online at https://www.unhcr.org/figures-at-a-glance.html.

Pace, R. (2013) "Migration in the Central Mediterranean Jean Monnet Occasional Paper 02/2102", University of Malta-EU Lifelong Learning Programme. Available online at https://www.um.edu. mt/_data/assets/pdf_file/0005/198527/JMProfPacePaperMigration022013webv6.pdf.

Paffenroth, A. (2014) "Outsourcing Conflict: An Analysis of the Strategic Underpinnings of Proxy Warfare", Thesis for MA in Global Security Studies. Washington: John Hopkins University. 
Palladino, M. and Gjergji, I. (2016) “Open 'Hearing' in a Closed Sea”, Interventions, International Journal of Postcolonial Studies 18(1): 1-18.

Pickering, S. (2005) Refugees and State Crime. Anandale: The Federation Press.

Robins-Early, N. (2015) "Hein de Haas 'Why the Debate Over Europe's Migration Crisis Is Full of Myths"”, Huffington Post, 29 August. Available online at http://www.huffingtonpost.com/entry/ europe-migrant-crisis-myths-facts_55df64e5e4b08dc09486d510.

Schmitt, M.N. and Vihul, L. (2014) "Proxy Wars in Cyber Space: The Evolving International Law of Attribution", Fletcher Security Review 1(2): 55-73.

The New Turkey. (2018) “Operation Olive Branch Secures Europe”, 25 January. Available online at https://thenewturkey.org/operation-olive-branch-secures-europe/.

UCDP website. (n.d.) "Uppsala Conflict Data Program, Definitions, 'Intensity””. Available online at http://www.pcr.uu.se/research/ucdp/definitions/.

UNHCR Syria. (2018) "Regional Refugee Response Inter-agency Information Sharing Portal”. Available online at http://data.unhcr.org/syrianrefugees/regional.php.

Weber, L. and Pickering, S. (2011) Globalization and Borders: Death at the Global Frontier. London and New York: Palgrave Macmillan.

Webber, F. (2017) “Europe's Unknown War”, Race and Class 59(1): 36-53. 